OPEN ACCESS

Edited by:

Francesco Fazi,

Sapienza University of Rome, Italy

Reviewed by:

Enrico Maggi,

University of Florence, Italy

Saula Checquolo,

Sapienza University of Rome, Italy

*Correspondence:

Simona Sivori

simona.sivori@unige.it

Emanuela Marcenaro

emanuela.marcenaro@unige.it

tThese authors have contributed equally to this work

FThese authors share senior authorship

Specialty section: This article was submitted to

Stem Cell Research,

a section of the journal Frontiers in Cell and Developmental

Biology

Received: 30 November 2019 Accepted: 11 February 2020

Published: 25 February 2020

Citation:

Pesce S, Greppi M, Ferretti E. Obino V, Carlomagno S, Rutigliani M, Thoren FB, Sivori S, Castagnola P, Candiani S and Marcenaro E (2020) miRNAs in NK Cell-Based Immune Responses and Cancer Immunotherapy.

Front. Cell Dev. Biol. 8:119. doi: 10.3389/fcell.2020.00119

\section{miRNAs in NK Cell-Based Immune Responses and Cancer Immunotherapy}

\author{
Silvia Pesce ${ }^{1 \dagger}$, Marco Greppi ${ }^{1,2 \dagger}$, Elisa Ferretti ${ }^{1,2}$, Valentina Obino ${ }^{1,2}$, \\ Simona Carlomagno ${ }^{1}$, Mariangela Rutigliani ${ }^{3}$, Fredrik B. Thoren ${ }^{4}$, Simona Sivori ${ }^{1,2 *}$, \\ Patrizio Castagnola ${ }^{5 \neq}$, Simona Candiani ${ }^{6 \neq}$ and Emanuela Marcenaro ${ }^{1,2 * \neq}$ \\ ${ }^{1}$ Department of Experimental Medicine, University of Genoa, Genoa, Italy, ${ }^{2}$ Center of Excellence for Biomedical Research, \\ University of Genoa, Genoa, Italy, ${ }^{3}$ Histological and Anatomical Pathology Unit, Department of Laboratory and Service, E.O. \\ Galliera Hospital, Genova, Italy, ${ }^{4}$ Tumor Immunology Laboratory (TIMM) Laboratory at Sahlgrenska Cancer Center, \\ Department of Infectious Diseases, Institute of Biomedicine, University of Gothenburg, Gothenburg, Sweden, ${ }^{5}$ IRCCS \\ Ospedale Policlinico San Martino, UO Bioterapie, Genoa, Italy, ${ }^{6}$ Department of Earth Science, Environment and Life \\ (DISTAV), University of Genoa, Genoa, Italy
}

The incidence of certain forms of tumors has increased progressively in recent years and is expected to continue growing as life expectancy continues to increase. Tumor-infiltrating NK cells may contribute to develop an anti-tumor response. Optimized combinations of different cancer therapies, including NK cell-based approaches for targeting tumor cells, have the potential to open new avenues in cancer immunotherapy. Functional inhibitory receptors on NK cells are needed to prevent their attack on healthy cells. Nevertheless, disruption of inhibitory receptors function on NK cells increases the cytotoxic capacity of NK cells against cancer cells. MicroRNAs (miRNAs) are small non-coding RNA molecules that target mRNA and thus regulate the expression of genes involved in the development, maturation, and effector functions of NK cells. Therapeutic strategies that target the regulatory effects of miRNAs have the potential to improve the efficiency of cancer immunotherapy. Interestingly, emerging evidence points out that some miRNAs can, directly and indirectly, control the surface expression of immune checkpoints on NK cells or that of their ligands on tumor cells. This suggests a possible use of miRNAs in the context of anti-tumor therapy. This review provides the current overview of the connections between miRNAs and regulation of NK cell functions and discusses the potential of these miRNAs as innovative biomarkers/targets for cancer immunotherapy.

Keywords: human NK cells, NK cell receptors, microRNA, immune checkpoint, immunotherapy, gene expression

\section{miRNAs AS KEY REGULATORS OF GENE EXPRESSION}

About 2,000 human miRNAs are currently recognized. These are small RNAs which originate from longer precursors (Pri-miRNAs) mainly transcribed by the RNA polymerase II (Macfarlane and Murphy, 2010). These Pri-miRNAs undergo a precisely coordinated maturation process involving several steps. In the nucleus, the RNAse III Drosha, supported by the DiGeorge critical region 8 (DGCR8), converts them in short hairpin intermediates of 70-120 nucleotides-long 
(Pre-miRNAs) (Gregory et al., 2004). After transport to the cytoplasm by exportin 5 (Yi et al., 2003), Pre-miRNAs are then processed by the RNAse III Dycer into mature miRNAs which are duplexes of approximately 22 nucleotides. One strand of the duplex is incorporated along with the argonaute protein in the miRNA-induced silencing complex RISC (Diederichs and Haber, 2007). These complexes promote the pairing of miRNA nucleotide sequences to their target sequences on $3^{\prime}$ UTR sequences of mRNAs and RISC cofactors mediate sitespecific cleavage, degradation of the target mRNA, or inhibition of its translation in protein $(\mathrm{Gu}$ and Kay, 2010). It is wellknown that miRNA can repress the expression of hundreds of different mRNAs. Furthermore, as several different miRNA target sequences may be present on the $3^{\prime}$ UTR of a single mRNA, complex networks of cooperative regulation by several miRNAs may affect the stability or the translation of a multitude of mRNAs (Filipowicz et al., 2008; Liu et al., 2009, 2014). As miRNA recognition sequences appear to be present on most of the protein-coding human mRNAs, the role of miRNAs as regulators of gene expression is quite relevant in mammalian development physiology and pathology (Dallaire and Simard, 2016; Peng and Croce, 2016; Ivanova et al., 2018; Johnson, 2019; Horsburgh et al., 2017). Therefore, miRNAs and in particular those present in body fluids and blood, either as free molecules or included in extracellular vesicles, are receiving increasing attention as possible disease biomarkers (Mori et al., 2019).

\section{NK CELLS AS INNATE IMMUNE CELLS WITH A KEY ROLE IN FIGHTING VIRAL INFECTIONS AND IN THE SURVEILLANCE AGAINST MALIGNANT TRANSFORMATION}

Natural Killer (NK) cells represent cytotoxic, innate lymphoid cells (ILCs) (Cortez and Colonna, 2016), and their main function is to provide the organism with a rapid immune response against infections, autologous transformed cells, and allogeneic cells (Vivier et al., 2011; Del Zotto et al., 2017; Freud et al., 2017). In fact, NK cells do not need to be primed with antigens to become fully functional and the mechanisms of non-self recognition do not rely on genomic recombination and subsequent cell clone expansion events.

Nowadays it is recognized that these cells mediate immunesurveillance also via regulatory functions by secreting cytokines, primarily interferon- $\gamma$ (IFN- $\gamma$ ) and tumor necrosis factor- $\alpha$ (TNF- $\alpha$ ), and by interacting with other immune or adaptive immune cells (Marcenaro et al., 2006; Vivier et al., 2011; Riise et al., 2015; Pesce et al., 2017b; Bernson et al., 2019). In turn, NK cells can respond to different types of chemokines and cytokines produced by other immune cells (Marcenaro et al., 2005a,b, 2006; Moretta et al., 2006; Parodi et al., 2015; Pesce et al., 2016).

NK cells are not a homogeneous population, but there are different NK subsets that differ in phenotype, maturational step, and functions. Among circulating mature NK cells, two main subsets can be identified: regulatory NKs $\left(\mathrm{CD} 56^{\text {bright }} / \mathrm{CD} 16^{-}\right)$, which are the most abundant in secondary lymphoid organs
(SLO) and display the ability to secrete high amounts of proinflammatory cytokines, and cytotoxic NKs $\left(\mathrm{CD} 56^{\mathrm{dim}} / \mathrm{CD} 16^{+}\right)$, which represent about $90 \%$ of circulating NK cells (Farag and Caligiuri, 2006; Carrega and Ferlazzo, 2012; Del Zotto et al., 2017).

SLO have been suggested being the anatomical sites where NK cells complete their maturation process that is associated with the transition from a CD56 $6^{\text {bright }}$ to a CD $56^{\mathrm{dim}}$ phenotype, acquisition of self-tolerance and lytic activity (Romagnani et al., 2007; Yu et al., 2010).

Both the killing and immune-regulative functions of NK cells depend on a balance of activating or inhibiting signals that originate from NK receptors (NKRs) (activating NKRaNKR and inhibitory NKR -iNKR-, respectively). The iNKRs include the human leucocyte antigens (HLA) class I-specific Killer Ig-like receptors (KIRs) recognizing allotypic determinants shared by groups of classical HLA-ABC alleles (Moretta et al., 1996), the leukocyte immunoglobulin-like receptor subfamily B member 1 (LILRB1) that is specific for different HLA-class I molecules (Cosman et al., 1997), and the CD94/NKG2A heterodimer specific for HLA-E (Braud et al., 1998) ad well as additional non-HLA-I specific inhibitory receptors, including programmed cell death protein 1 (PD-1), T cell immunoreceptor with Ig and ITIM domains (TIGIT), Tcell immunoglobulin domain and mucin domain 3 (TIM3), lymphocyte-activation gene 3 (LAG-3), and CD96 (Di Vito et al., 2019). The activating NKRs (aKIRs) include non-HLA-specific receptors such as NCRs (NKp30, NKp44 and NKp46), NKG2D, DNAM-1, NKp80, CD59, NTB-A, and 2B4 (Moretta et al., 2001) as well as the activating HLA class I-specific Killer Ig-like receptors and the HLAE specific CD94/NKG2C heterodimer. NK cells can also express different Toll-like receptors (TLR), including TLR2, TLR3, TLR5, TLR7, TLR8, and TLR9 (Sivori et al., 2004; Hart et al., 2005; Tsujimoto et al., 2005; Marcenaro et al., 2008; Voo et al., 2014). These receptors, by recognizing conserved pathogen structures, induce NK cell activation (Della Chiesa et al., 2014).

During NK cell development/differentiation, CD94/NKG2A is the first HLA-I specific receptor to be expressed. It appears on the most immature CD56 $6^{\text {bright }} \mathrm{CD} 16^{\text {neg/dim }} \mathrm{NK}$ cell subset. After several maturation steps, CD56 ${ }^{\text {bright }}$ cells become CD56 ${ }^{\text {dim }}$ $\mathrm{CD}_{16}{ }^{+}$, lose NKG2A and acquire KIR and LILRB1 receptors (Di Santo, 2006; Freud and Caligiuri, 2006; Romagnani et al., 2007). The most mature NK cells are $\mathrm{KIR}^{+}$(and/or LILRB1 ${ }^{+}$), $\mathrm{NKG}_{2} \mathrm{~A}^{-} \mathrm{CD} 16^{\text {bright }}$ and express the marker of terminal differentiation, CD57 (Moretta et al., 2004; Bjorkstrom et al., 2010; Marcenaro et al., 2017).

Under homeostatic conditions, NK cells continuously receive inhibitory signals mainly originating from the interaction between iNKRs and a large spectrum of classical and nonclassical HLA-I molecules expressed on the surface of autologous cells (self-cells). Allogeneic or viral-infected or tumor cells often downregulate or lack altogether the expression of these antigens and therefore fail to be recognized as selfcells by the iNKRs. Under these conditions, the signaling from the aNKRs, engaged with ligands displayed on target 
cells, prevails, and the NK-mediated killing of these nonself cells is unleashed. Notably, in tumors that maintain the expression of HLA-I molecules, the iNKRs function as immune checkpoints and block the cytotoxic activity of NK cells (Romagne et al., 2009; Vey et al., 2012; Kohrt et al., 2014).

Several strategies have been forwarded to strenghten NK cell activity against HLA-I-expressing cancer cells. For example, IL2-based immunotherapy allows NK cells to override inhibitory signals from acute myeloid leukemia (AML) blasts (Hallner et al., 2019), and recently, immunotherapies based on the use of therapeutic monoclonal antibodies specific for iNKRs, in particular anti-pan-KIR2D (lirilumab) (Romagne et al., 2009; Kohrt et al., 2014; Vey et al., 2018) and anti-NKG2A (monalizumab), have been developed (André et al., 2018; Tinker et al., 2019; Zaghi et al., 2019). These agents efficiently disrupt the interaction between these NK cell immune checkpoints and their ligands, and will in this way enable NK cells to efficiently kill also HLA-I $^{+}$tumor cells (Chiossone et al., 2017; Di Vito et al., 2019).

In addition, the microenvironment of chronic infections and tumors may lead to NK cell phenotypic changes and impairment of NK cell functions (Bi and Tian, 2017). The most frequently NK cell phenotypic changes are represented by downregulation of the aNKRs expression (Costello et al., 2002; Romero et al., 2006; Carlsten et al., 2009; Pesce et al., 2015; Han et al., 2018; Poznanski and Ashkar, 2019) and/or upregulation/de novo expression of iNKRs (Carlsten et al., 2009; Di Vito et al., 2019; SanchezCorrea et al., 2019). In fact, it has been unveiled that besides $\mathrm{T}$ lymphocytes also NK cells can express PD-1, an immune checkpoint specific for the PD-L1/2 molecules often displayed on the surface of tumor cells (Pesce et al., 2019b).

PD-1 is expressed on a subset of fully mature $\left(\mathrm{KIR}^{+} \mathrm{CD} 7^{+} \mathrm{NKG}^{-} \mathrm{A}^{-}\right) \mathrm{NK}$ cells from one-fourth of human cytomegalovirus (HCMV) seropositive individuals (Della Chiesa et al., 2016; Pesce et al., 2017a; Mariotti et al., 2019). Increased proportions of $\mathrm{PD}-1^{+} \mathrm{NK}$ cells can be observed in patients affected by different types of tumors (Beldi-Ferchiou et al., 2016; Pesce et al., 2017a, 2019a,b; André et al., 2018). Accordingly, studies suggest a role for NK cells in immunotherapy targeting the PD-1/PD-L1 axis (Hsu et al., 2018) and this is clinically relevant for patients with tumors characterized by a $\mathrm{T}$ cell resistant (HLA-I ${ }^{\text {neg }}$ ) phenotype.

Apart from the wide-spread use of checkpoint inhibitors in melanoma, lung cancer etc., agents blocking the PD-1/PDL1 axis are currently being evaluated in clinical trials on both hematologic and solid tumors as monotherapy or in combination with other agents, including other forms of immune checkpoint blockade, such as anti-panKIR2D and anti-NKG2A antibodies in the case of HLA-I ${ }^{+}$tumor cells (Moretta et al., 1996, 2001; Cosman et al., 1997; Braud et al., 1998; Sivori et al., 2004; Marcenaro et al., 2008; Di Vito et al., 2019).

In summary, NK cell activation depends on the nature of interactions between inhibitory/activating receptors on their surface and the relative ligands on target cells, and thus receptor/ligand pairs could represent key checkpoints in the regulation of anti-tumor NK cell activity and in the planning of innovative NK cell-based immunotherapy.

\section{miRNAs AS REGULATORS OF NK CELLS SURVIVAL, DEVELOPMENT/MATURATION, AND FUNCTIONS}

Numerous studies showed that miRNAs play a relevant role in the regulation of NK cell survival, development/maturation, activation, proliferation, cytotoxicity, and cytokine production both in healthy and pathological conditions (i.e., tumors/viral infections) by targeting receptors or factors involved in transcriptional expression (Table 1).

\section{miRNAs Involved in NK Cell Differentiation/Development}

The first evidence of the important role played by miRNAs within the immune system was provided by genetic studies showing a critical requirement for Dicer in vivo. Conditional deletion of Dicer in various hematopoietic lineages in mice produced defects, such as impaired cell differentiation, proliferation, and survival (Muljo et al., 2005; Cobb et al., 2006; Koralov et al., 2008; Liston et al., 2008; Fedeli et al., 2009).

Bezman et al. (2010) investigated the role of miRNAs by ablation of the miRNA biogenesis pathway, through deletion of Dicer or Dgcr8 in the mature murine peripheral NK cells. Dicerand Dgcr8- deficient NK cells showed an increased cell death supporting the important role of miRNAs in controlling cell survival. Moreover, Dicer- and Dgcr8-deficient NK cells are able to respond efficiently through their cytokine receptors; however, function of their immunoreceptor tyrosine-based activation motif (ITAM)-containing aKIRs is impaired.

By using another molecular approach, Sullivan et al. (2012) eliminated Dicer during the earliest stages of murine NK cell development in the bone marrow to better characterize the phenotypic features derived from global loss of mature miRNA expression. These studies confirmed that the absence of miRNAs led to reduced numbers and percentages of NK cells, and a decreased in vitro survival/proliferation.

Studies utilizing next-generation sequencing in mouse and human reported some information about the miRNA repertoire in resting $\mathrm{CD}_{5} 6^{+} \mathrm{CD} 3^{-}$human or $\mathrm{NK} 1.1^{+} \mathrm{CD}^{-}$murine $\mathrm{NK}$ cells and upon cytokine activation (Fehniger et al., 2010; Liu et al., 2012; Wang et al., 2012). Furthermore, Ni et al. (2015) identified the miRNA profiles of human NK cells from different compartments (peripheral blood, cord blood, and uterine decidua). Very recently, our group, by analyzing peripheral blood NK cells from 10 different human healthy donors, identified a 108 miRNA signature able to discriminate CD56 bright from CD56 $6^{\text {dim }}$ NK cell subsets independently from their surface phenotype (Pesce et al., 2018). Interestingly, we found some miRNAs (miR146a-5p, miR-92a-3p, miR-223-3p, miR-873-5p, miR-31a-5p, hsa-miR-130a-5p, miR-181a-2-3p) with consistent differential expression in the two NK cell subsets, and with an intermediate expression in the CD56 $6^{\text {bright }} / \mathrm{CD} 16^{\mathrm{dim}} \mathrm{NK}$ cell subset, which represents a transition phase in the NK cell maturation process of NK cells.

A key miRNA for NK cell development is miR-150. A gain of function miR-150 transgene in mouse was demonstrated to 
TABLE 1 | Examples of miRNAs expressed in NK cells and involved in the modulation of several aspects of NK cell development and functions.

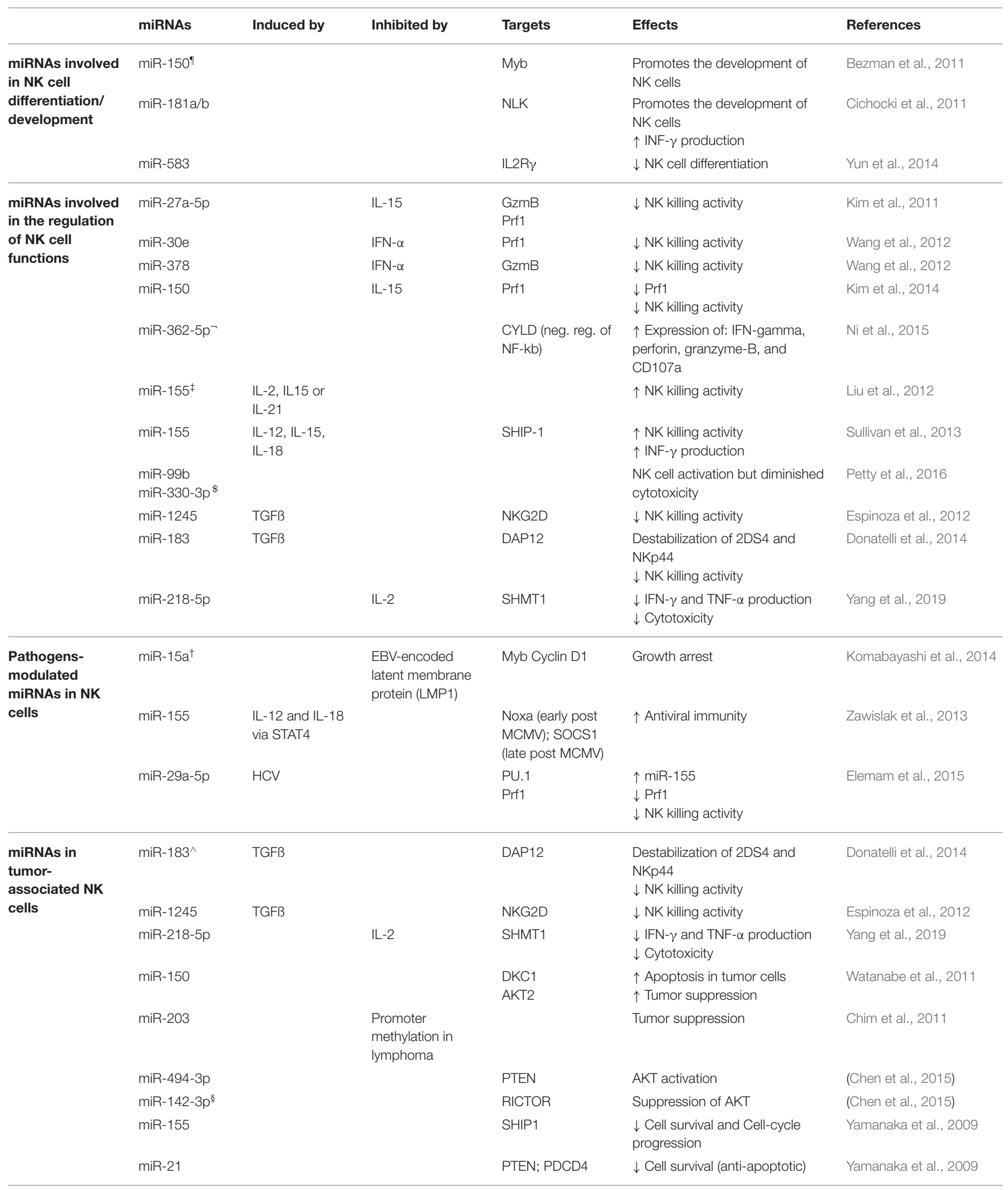


TABLE 1 | Continued

\begin{tabular}{|c|c|c|c|c|c|c|}
\hline & miRNAs & Induced by & Inhibited by & Targets & Effects & References \\
\hline & $\begin{array}{l}\text { miR-26a/b } \\
\text { miR-28-5 } \\
\text { miR-30b } \\
\text { miR-101 } \\
\text { miR-363 }\end{array}$ & & c-Myc & $\begin{array}{l}\text { MUM1, BLIMP1, } \\
\text { and STMN1 in } \\
\text { NKTL }\end{array}$ & $\begin{array}{l}\downarrow \text { Cell growth (NK/T-cell } \\
\text { Lymphoma) }\end{array}$ & Ng et al., 2011 \\
\hline & miR26a/b & & & $\mathrm{BCL} 2$ & $\downarrow$ Cell growth & Ng et al., 2011 \\
\hline & miR-101 & & & $\begin{array}{l}\text { STMN1IGF1 } \\
\text { BCL2 }\end{array}$ & $\downarrow$ Cell growth & Ng et al., 2011 \\
\hline & $\begin{array}{l}\text { miRNA-10a } \\
\text { miRNA-342-3p }\end{array}$ & & & TIAM1 & $\begin{array}{l}\text { Low miRNA expression } \\
\text { correlated with development of } \\
\text { Extranodal NK/T-cell lymphoma }\end{array}$ & Huang et al., 2016 \\
\hline & miR-221 & & & & $\begin{array}{l}\text { Poor Survival in Plasma NK/T-cell } \\
\text { Lymphoma }\end{array}$ & Guo et al., 2010 \\
\hline \multirow{3}{*}{$\begin{array}{l}\text { miRNAs involved } \\
\text { in the regulation } \\
\text { of NK cell } \\
\text { immune } \\
\text { checkpoints }\end{array}$} & miR-182\# & & & NKG2D? NKG2A? & $\begin{array}{l}\uparrow \text { Cytotoxicity via Prf1 counter } \\
\text { intuitive effects on NKG2D and } \\
\text { NKG2A }\end{array}$ & $\begin{array}{l}\text { Abdelrahman et al., 2016; } \\
\text { El Sobky et al., } 2016\end{array}$ \\
\hline & $\operatorname{miR}-146 a-5 p^{\circ}$ & & & KIR2DL1 KIR2DL2 & $\uparrow N K$ killing activity & Pesce et al., 2018 \\
\hline & $\begin{array}{l}\text { miR-26b-5p } \\
\text { miR-26a-5p } \\
\text { miR-185-5p }\end{array}$ & & & KIR3DL3 & NK cell activation? & Nutalai et al., 2019 \\
\hline
\end{tabular}

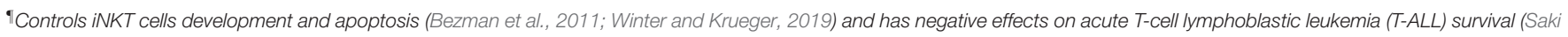
et al., 2015) whereas it has a protective effect on $C D 4^{+}$and $C D 8^{+} T$ cells by controlling the expression of pro-apoptotic genes (Cron et al., 2019).

-Promotes malignancy of chronic lymphocytic leukemia (CLL) (Yang et al., 2015).

${ }^{\ddagger}$ Reported to be also involved in CD8+ T cell activation (Gracias et al., 2013) and T cell development.

$\$$ Also involved in the inhibition of TGF- $\beta$ expression in CD8+ Treg cells (Rouas et al., 2019).

${ }^{\dagger}$ Also involved in the control of chronic lymphocytic leukemia clonal expansion (Cutrona et al., 2017).

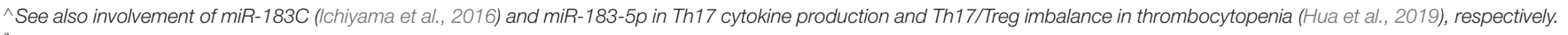
$\S$ Also involved in CD25+ CD4 T cell proliferation by targeting the expression of GARP (Zhou et al., 2013).

\#Also Promotes clonal expansion of activated Thelper lymphocytes (Stittrich et al., 2010).

- Promotes growth of acute leukemia cells (Wang L. et al., 2019).

drive the development and maturation of NK cells. In line with this, mice with a targeted deletion of miR-150 instead display cell lineage-intrinsic defect in their ability to generate mature NK cells (Bezman et al., 2011).

Additional miRNAs relevant for NK cell development and maturation are miR-181 and miR-583. Cichocki and coworkers found that miR-181 promotes NK cell development via inhibition of the Nemo like kinase (NLK) (Cichocki et al., 2011) while Yun and collaborators showed that the miR-583 targets and downregulates IL2R $\gamma$ in NK cells acting as a negative regulator of their differentiation process (Yun et al., 2014).

\section{miRNAs Involved in the Regulation of NK Cell Functions}

Accumulating evidence suggests that distinct miRNAs may play regulative roles on NK cell functions both in terms of cytotoxicity and cytokine production. In this context, miR-27a-5p (Kim et al., 2011), miR-378, miR-30e (Wang et al., 2012), and miR150 (Kim et al., 2014), were proposed as negative regulators of NK cell killing ability. In particular, miR-378 was found to target granzyme b (Gzmb) (Wang et al., 2012), miR-30e and miR-150 have as target perforin (Prf1) (Wang et al., 2012; Kim et al., 2014) while miR-27a-5p targets both (Kim et al., 2011). By contrast, Prf1, Gzmb, IFN- $\gamma$, and CD107a in human NK cells were all upregulated after miR-362-5p overexpression. $\mathrm{Ni}$ and collaborators indeed found that this miRNA targets the mRNA coding for the cylindromatosis lysine 63 deubiquitase (CYLD) and suggested that miR-362-5p promotes NK cell effector functions (Ni et al., 2015).

miR-155 should also be included among the miRNAs that enhance NK cell functions. In particular, IL-2, IL-15, and IL21 upregulate this miRNA, which in turn, enhances NK cell cytotoxicity (Liu et al., 2012). Moreover, miR-155 extensively regulates the NK cell activation threshold regulating molecules 
involved in $\mathrm{NK}$ cell activation and their IFN- $\gamma$ release by modulating the expression of the phosphatase SHIP-1, Tbet/Tim-3, or the activation of several signaling pathways, including those involving PI3K, NF-kB, and calcineurin (Trotta et al., 2012; Sullivan et al., 2013; Cheng et al., 2015). Similarly, miR-181 was also found to promote IFN- $\gamma$ production in primary NK cells in response to cytokine stimulation through regulation of the Notch pathway (Cichocki et al., 2011).

In a study aimed to identify miRNAs potentially involved in the pathogenesis of chronic fatigue syndrome or myalgia encephalomyelitis in peripheral blood mononucleate cells (PBMC), 34 miRNAs were found upregulated compared to healthy controls and 2 of these (miR-99b, miR-330-3p) were confirmed having the most important deregulation in NK cells in terms of cytotoxic activity (Petty et al., 2016).

\section{Pathogens-Modulated miRNAs in NK Cells}

The host's immune responses must be strictly regulated by an sophisticated balance between positive and negative signals during the fight against pathogens.

One of the mechanisms by which pathogens can break this balance is that of interfering with the regulatory role of miRNAs.

TLRs are receptors of the innate immune system that directly recognize conserved structures of both viral and bacterial origin that are present and functional on NK cells (Della Chiesa et al., 2014). It has been recently demonstrated that several miRNAs, including miR-21, miR-146, miR-155, and let-7 family can bind to TLRs (acting also as physiological ligands for these receptors) or proteins in TLR signaling pathways. These interactions can regulate the expression and the transcriptional responses of TLRs (Bayraktar et al., 2019). In addition, some miRNAs and miRNAcontaining exosomes can selectively activate innate immune effector cells, including NK cells, via the TLR1-NF-kB signaling pathway (He et al., 2013).

Enhancement of NK cell cytotoxicity with upregulation of Prf1 was described as associated with miR-182 overexpression in NK cells derived from hepatocellular carcinoma (HCC) patients (Abdelrahman et al., 2016). However, a subsequent study from the same group reported contradicting roles of this miRNA in both NK cells and in hepatocytes infected by hepatitis $\mathrm{C}$ virus (HCV) (El Sobky et al., 2016).

Komabayashi and collaborators demonstrated that the Epstein-Barr virus (EBV)-encoded latent membrane protein 1 (LMP1) is able to downregulate the expression of the miR-15a and increase MYB and cyclin D1 in cell lines with an NK cell phenotype (Komabayashi et al., 2014), thus suggesting that miR15 a may have a role in the repression of NK cell proliferation. In line with this, Cheng and collaborators found that the downregulation of miR-155 suppressed IFN- $\gamma$ production through Tim-3 signaling and lead to HCV evading immune clearance (Cheng et al., 2015). However, the specific target of miR-155 in the context of these two studies remains unknown.

miR-155 was found to be induced by IL-2 and IL-18 via STAT4 and able to reduce the expression of NOXA and SOCS1 at distinct stages of homeostasis and activation. As NK cells of mice with a targeted miR-155 deletion displayed dramatically diminished effector activities and reduce memory cell numbers in both lymphoid and non-lymphoid tissues afterwards murine cytomegalovirus (MCMV) infection, these findings suggest that miR-155 promotes antiviral immunity (Zawislak et al., 2013). However, a study by Elemam et al. (2015) reached contrasting conclusions as they observed that HCV infection might abolish NK cell cytotoxicity via modification of PU.1 (a key transcription factor in the NK cell development), and Prf1/NKG2D expression by miR-29a-5p and miR-155 overexpression, respectively.

\section{miRNAs in Tumor-Associated NK Cells}

Several studies demonstrated that miRNAs might also act as oncogenes or tumor suppressor genes in different human cancer histotypes. Most of the endogenous miRNAs that have been characterized so far modulate NK cell antitumor activity in the tumor microenvironment (TME). TGFß released by tumor cells in the TME is a powerful inhibitor of the NK cell killing activity, and Donatelli and collaborators have shown that a specific miRNA, miR183, is induced by TGFß (Donatelli et al., 2014). They also formally proved that this miRNA downregulates the expression of the DNAX activating protein $12 \mathrm{kDa}$ (DAP12) that was found critically involved in the stabilization of KIR2DS4 and NKp44 receptors on the plasma membrane and required for their signaling activities. Interestingly, loss of DAP12 was also identified as a common trait in tumor-infiltrating lymphocytes in lung cancer (Donatelli et al., 2014). TGFß has also been reported to increase post-transcriptionally the levels of mature miR-1245 which suppresses NKG2D expression, thus spoiling NKG2D-mediated immune responses and enhancing the tumor supporting properties of the TME (Espinoza et al., 2012).

Yang and collaborators reported that miR-218-5p suppresses the NK-mediated killing of lung adenocarcinoma by targeting Serine Hydroxymethyltransferase 1 (SHMT1) (Yang et al., 2019).

Several studies identified miRNAs (miR-203, miR-494-3p, miR-142-3p, miR-155, miR-21) that affect NK cell lymphoma survival and apoptosis modulating different pathways including the PTEN-AKT-mTOR pathway (Yamanaka et al., 2009; Chim et al., 2010, 2011; Ichimura et al., 2010; Chen et al., 2015).

Recent findings provided evidence on the role of some miRNAs as tumor suppressors, such as miR-150 that is involved in the pathogenesis of malignant lymphoma, by increasing the incidence of apoptosis and reducing cancer cell proliferation (Watanabe et al., 2011).

Several studies were performed using as model the NK/T cell lymphoma (NKTL), a progressive malignancy with unfavorable prognosis without a specific treatment, and most of them were pursued to identify dysregulated miRNAs that can affect targets involved in the oncogenesis of NKTL. In this context, $\mathrm{Ng}$ and collaborators found that miR-26a, miR-26b, miR-28-5, miR-30b, miR-101, and miR-363 were downregulated, possibly via MYC, in NKTL and NK cell lines compared to normal NK cells and that the suppressed miRNA expression allowed increased expression of genes implicated in oncogenesis (Ng et al., 2011). Furthermore, in a recent study focused on NKTL, Huang and collaborators reported data suggesting that miR-10a and miR-342-3p may be implicated in the development of NKTL through the Tlymphoma invasion and metastasis inducing factor 1 (TIAM1) pathway, which has a crucial role in the development of several 
types of human cancer (Huang et al., 2016). Other miRNAs such as miR-221 and miR-155, associated with promotion of NKTL viability, have been proposed as potential molecular markers of NKTL (Guo et al., 2010; Chang et al., 2019).

Recently, growing evidence has shown that extracellular vesicles (EVs) released by NK cells transport miRNAs capable of exerting a strong anti-tumor effect in immunosuppressive TME (Fabbri, 2020). Previous studies have also demonstrated that NK cell-derived exosomes have tumor-specific accumulation with no cytotoxic activity against normal tissues (Lugini et al., 2012). Meanwhile, microenvironment acidic $\mathrm{pH}$ promotes the traffic of this EVs in tumor cells (Parolini et al., 2009). In addition, NK cellderived exosomes also exhibit the benefits of being stable vesicles and maintain their biological activities. Thus, NK cell-derived exosomes can both facilitate tumor targeting and act as direct antitumor agent. These properties make them more suitable for clinical applications, thus suggesting a possible use of NK-cell derived EVs as anticancer agents as a new avenue for tumor therapy (Wang H. et al., 2019).

\section{miRNAs Involved in the Regulation of NK Cell Immune Checkpoints}

Immune checkpoints have a key role in regulating the intensity of immune responses of lymphocytes by performing inhibitory functions. The use of immune checkpoint inhibitors in immunotherapy has driven anti-cancer treatment on a novel level. Emerging evidence suggests that some miRNAs can control the expression of immune checkpoints on the surface of NK cells or that of their ligands on tumor cells. This suggests a possible use of miRNAs in the context of anti-tumor therapy.

In a recent study we proved that the miR-146a-5p is able to downregulate both KIR2DL1 and KIR2DL2, two HLA-specific inhibitory receptors belonging to KIR family (Pesce et al., 2018) (Figure 1A). Furthermore, in silico functional characterization of miR-146a-5p gene targets, identified CD94, HLA-C, HLA-E, Prf1, and several other KIRs genes as additional targets. These results are in line with the higher levels of miR-146a-5p found in CD56 ${ }^{\text {bright }} \mathrm{NK}$ cells and with other studies suggesting that this miRNA is engaged in the regulation of NK cell maturation via the STAT1 (Xu et al., 2017) and NF-kappaB (Wang et al., 2018) signaling pathways. A different research group identified very recently three miRNAs, miR-26a-5p, miR-26b-5p, and miR185-5p, as inhibitors of the expression of an additional KIR, the KIR3DL3, which is included in the iNKRs group but it is still poorly characterized (Nutalai et al., 2019) (Figure 1A). Therefore, the role of these miRNAs in NK cells development or function remains to be defined.

The study of Abdelrahman and collaborators showed that enhancement of NK cell cytotoxicity by miR-182 in human hepatocellular carcinoma and increased Prf1 expression were indirect effects likely mediated by a complex modulation of NKG2D and NKG2A levels in these cells at different stages of the disease (Abdelrahman et al., 2016) (Figure 1B).

Regarding miRNAs regulating PD-1 expression, miR-28 (Li et al., 2016), miR138 (Wei et al., 2016), and miR-4717 (Zhang et al., 2015) have been found to target this immune checkpoint, and to induce $\mathrm{T}$ cell exhaustion. It has been demonstrated that miR-4717 play a role in chronic Hepatitis B Virus (HBV) infection, where this miRNA is significantly reduced (Zhang et al., 2015). Since also NK cells may express PD-1, it cannot be excluded that these miRNAs may play an important regulatory role also in these innate cells.

Notably, some mi-RNAs target additional immune checkpoints playing a critical role for cytotoxic immune cell functions, such as miR-28 targeting TIM-3 (Li et al., 2016), expressed by both T and NK cells (Di Vito et al., 2019), and miR-16, miR-138, and miR-195 targeting cytotoxic T-lymphocyte antigen 4 (CTLA-4), mainly expressed by $\mathrm{T}$ cells (Wei et al., 2016; Tao et al., 2018).

\section{miRNAs Involved in the Regulation of the Expression of Ligands for NK Cell Receptors}

Tumor immune evasion is not restricted to the upregulation of immune checkpoint proteins, but also to the dysregulation in the expression of immune checkpoint ligands, including classical and non-classical HLA-I molecules or ligands for activating NK cell receptors. In this context, it has been found that miR-9 is involved in the downmodulation of the expression of HLA-I molecules in human cancer cells, preventing the detection of cancer cells by the immune system (Gao et al., 2013) (Figure 1C). This suggests that tumors overexpressing this miRNA might become resistant to $\mathrm{CD}^{+}$T-cell mediated killing but susceptible to NK cellmediated attack. In addition, the tumor-suppressive miR-148 family has been found to regulate the expression of HLA-G, a ligand for different NK cell inhibitory receptors (Mandelboim et al., 1997; Seliger, 2016) (Figure 1D).

Recently, it has been demonstrated that some miRNAs directly target the $3^{\prime}$-UTR of PD-L1 mRNA and others the PD1/PD-L1 indirectly by targeting the related signaling pathways (Wang et al., 2017; Gao et al., 2019; Omar et al., 2019). miR$15 \mathrm{a}, \mathrm{miR}-15 \mathrm{~b}$ and $\mathrm{miR}-16$ were discovered to downregulate the PD-L1 expression in malignant pleural mesothelioma cell line (Kao et al., 2017) (Figure 1D). miR-34a was found to be inversely correlated with PD-L1 expression in 44 AML samples (Wang et al., 2015) (Figure 1D). miR-935p, miR106b-5p, miR-138-5p, miR-142-5p, miR-193a-3p, miR-200, and miR-570 overexpression downregulate PD-L1 in tumor cell lines of different hystotypes (Chen et al., 2014; Guo et al., 2015; Cioffi et al., 2017; Jia et al., 2017; Kao et al., 2017) (Figure 1D). miR-152 was found to regulate PD-L1 in gastric cancer tissues (Guo et al., 2015), while miR-424 regulates the PD-L1 expression in chemo-resistant ovarian cancer patients (Xu et al., 2016) (Figure 1D). Notably, miR-873 decreased the stemness and resistance to chemotherapy of breast cancer cells, depending on PD-L1 and the downstream PI3K/Akt and ERK1/2 signaling, by directly inhibiting PD-L1 expression. This suggests that miR-873/PD-L1 regulatory axis may represent a new therapeutic target in breast cancer. Such data are interesting for employing miRNAs as useful diagnostic targets and valuable biomarkers for prognosis in the PD-1/PD-L1 blockade therapy. miR-155, a key component of inflammatory responses, is 


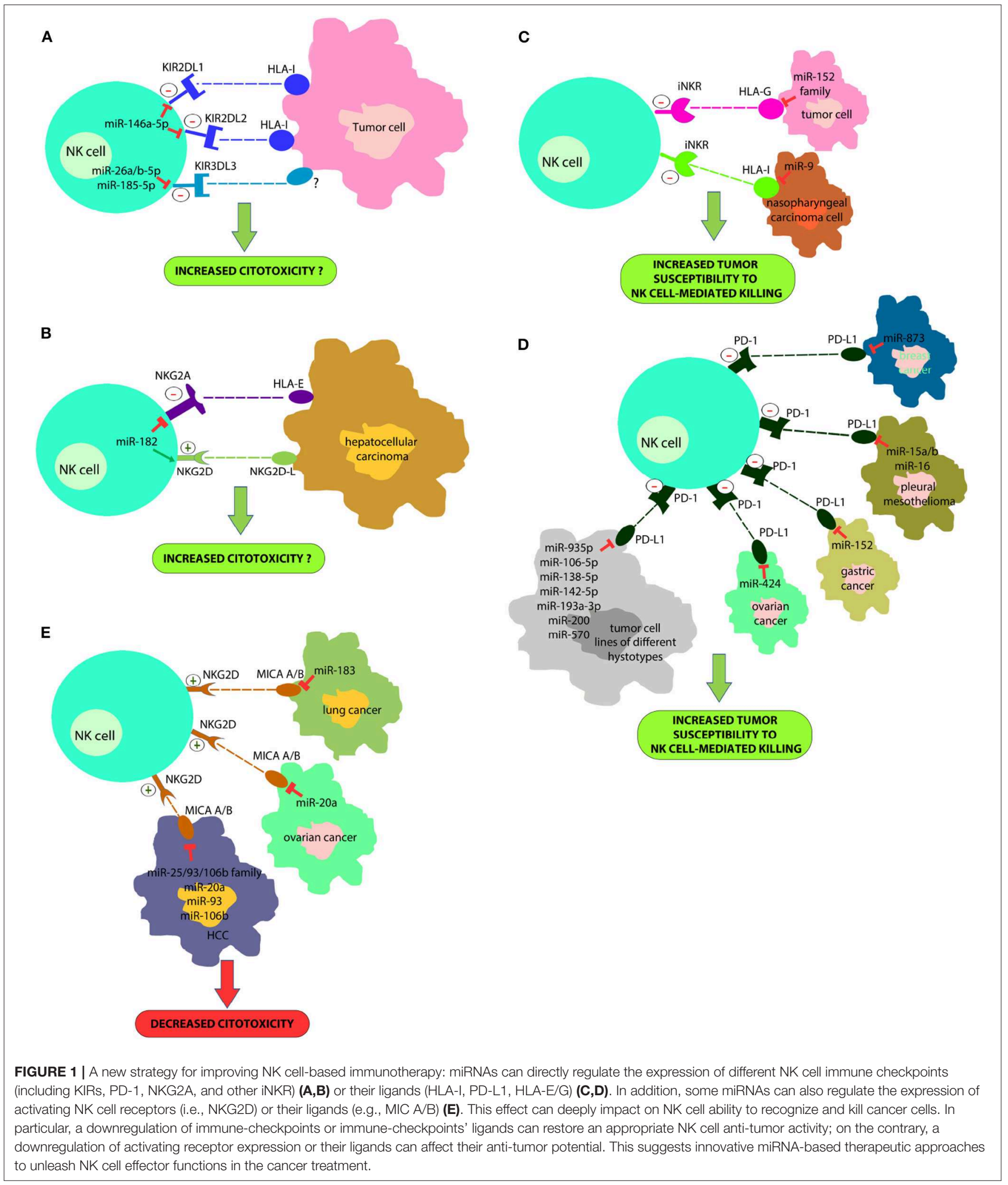

dysregulated in different cancer cell types. In this context, it has been recently demonstrated that the induction of miRNA155 expression, suppresses the expression of PD-L1 in both primary lymphatic endothelial cells and fibroblasts, by exposing these cells to the TNF-a and IFN- $\gamma$ proinflammatory cytokines (Yee et al., 2017). 
Moreover, different miRNAs downregulate MHC class I chain-related protein A/B (MICA/B) expression (NKG2D NKcell receptor ligands) and this represents another mechanism of immune suppression targeting NK cells cytotoxicity. These miRNAs include miR-183 that targets MIC A/B in lung cancer (Trinh et al., 2019), miR-20a that induces the same effect in ovarian cancer (Xie et al., 2014) and miR-25/93/106b family, miR20a, miR-93 and miR-106b that act in HCC (Kishikawa et al., 2013) (Figure 1E).

\section{CONCLUDING REMARKS}

Recently, there has been a substantial evolution in cancer therapy, mainly oriented toward immunotherapy approaches, in substitution or in combination with classical therapy. Cancer immunotherapy represents a promising new era in cancer management due to the relatively high safety margins and selectivity, compared to the classical cancer chemotherapeutic agents.

miRNAs have come to light over the last years as key actors in epigenetic regulation and for their capacity to modulate tumor immunity by directly regulating the expression of genes involved in the activation or suppression of the immune response. In this review, we focused our attention on the current state of knowledge concerning the involvement of

\section{REFERENCES}

Abdelrahman, M. M., Fawzy, I. O., Bassiouni, A. A., Gomaa, A. I., Esmat, G., Waked, I., et al. (2016). Enhancing NK cell cytotoxicity by miR-182 in hepatocellular carcinoma. Hum. Immunol. 77, 667-673. doi: 10.1016/j.humimm.2016.04.020

André, P., Denis, C., Soulas, C., Bourbon-Caillet, C., Lopez, J., Arnoux, T., et al. (2018). Anti-NKG2A mAb is a checkpoint inhibitor that promotes antitumor immunity by unleashing both T and NK cells. Cell 175, 1731-1743.e13. doi: 10.1016/j.cell.2018.10.014

Bayraktar, R., Bertilaccio, M. T. S., and Calin, G. A. (2019). The interaction between two worlds: microRNAs and toll-like receptors. Front. Immunol. 10:1053. doi: 10.3389/fimmu.2019.01053

Beldi-Ferchiou, A., Lambert, M., Dogniaux, S., Vély, F., Vivier, E., Olive, D., et al. (2016). PD-1 mediates functional exhaustion of activated NK cells in patients with Kaposi sarcoma. Oncotarget 7, 72961-72977. doi: 10.18632/oncotarget.12150

Bernson, E., Christenson, K., Pesce, S., Pasanen, M., Marcenaro, E., Sivori, S., et al. (2019). Downregulation of HLA class I renders inflammatory neutrophils more susceptible to NK cell-induced apoptosis. Front. Immunol. 10:2444. doi: 10.3389/fimmu.2019.02444

Bezman, N. A., Cedars, E., Steiner, D. F., Blelloch, R., Hesslein, D. G. T., and Lanier, L. L. (2010). Distinct requirements of microRNAs in NK cell activation, survival, and function. J. Immunol. 185, 3835-3846. doi: 10.4049/jimmunol.1000980

Bezman, N. A., Chakraborty, T., Bender, T., and Lanier, L. L. (2011). miR-150 regulates the development of NK and iNKT cells. J. Exp. Med. 208, 2717-2731. doi: 10.1084/jem.20111386

Bi, J., and Tian, Z. (2017). NK cell exhaustion. Front. Immunol. 8:760. doi: 10.3389 /fimmu.2017.00760

Bjorkstrom, N. K., Riese, P., Heuts, F., Andersson, S., Fauriat, C., Ivarsson, M. A., et al. (2010). Expression patterns of NKG2A, KIR, and CD57 define a process of CD56dim NK-cell differentiation uncoupled from NK-cell education. Blood 116, 3853-3864. doi: 10.1182/blood-2010-04-281675
miRNAs in various physiologic processes of NK cells. In particular, we discussed their abilty to regulate NK immune responses and their potential implications in resistance to cancer immunotherapy, with main focus on immune checkpoints. In this context, several miRNAs have been found to modulate different immune checkpoints/ligands interaction, including the PD-1/PD-L1 axis or their upstream genes. Future studies comparing miRNAs' expression profiles in patients who respond to immune checkpoint blockade immunotherapies as compared to non-responders will help to disclose the potential role of miRNAs as noninvasive predictive biomarkers for monitoring the response and clinical outcomes to immunotherapy with immune checkpoint inhibitors.

\section{AUTHOR CONTRIBUTIONS}

All authors listed have made a substantial, direct and intellectual contribution to the work, and approved it for publication.

\section{FUNDING}

This work was supported by Fondazione Associazione Italiana per la Ricerca sul Cancro (IG 2017-20312 and 5x1000-21147); Fondazione Roche (Progetto Roche per la Ricerca 2017).
Braud, V. M., Allan, D. S. J., O'Callaghan, C. A., Söderström, K., D'Andrea, A., Ogg, G. S., et al. (1998). HLA-E binds to natural killer cell receptors CD94/NKG2A, B and C. Nature 391, 795-799. doi: 10.1038/35869

Carlsten, M., Norell, H., Bryceson, Y. T., Poschke, I., Schedvins, K., Ljunggren, H.-G., et al. (2009). Primary human tumor cells expressing CD155 impair tumor targeting by down-regulating DNAM-1 on NK cells. J. Immunol. 183, 4921-4930. doi: 10.4049/jimmunol.0901226

Carrega, P., and Ferlazzo, G. (2012). Natural killer cell distribution and trafficking in human tissues. Front. Immunol. 3:347. doi: 10.3389/fimmu.2012.00347

Chang, Y., Cui, M., Fu, X., Zhang, L., Li, X., Li, L., et al. (2019). MiRNA-155 regulates lymphangiogenesis in natural killer/T-cell lymphoma by targeting BRG1. Cancer Biol. Ther. 20, 31-41. doi: 10.1080/15384047.2018.1504721

Chen, H.-H., Huang, W.-T., Yang, L.-W., and Lin, C.-W. (2015). The PTEN-AKTmTOR/RICTOR pathway in nasal natural killer cell lymphoma is activated by miR-494-3p via PTEN but inhibited by miR-142-3p via RICTOR. Am. J. Pathol. 185, 1487-1499. doi: 10.1016/j.ajpath.2015.01.025

Chen, L., Gibbons, D. L., Goswami, S., Cortez, M. A., Ahn, Y.-H., Byers, L. A., et al. (2014). Metastasis is regulated via microRNA-200/ZEB1 axis control of tumour cell PD-L1 expression and intratumoral immunosuppression. Nat. Commun. 5:5241. doi: 10.1038/ncomms6241

Cheng, Y. Q., Ren, J. P., Zhao, J., Wang, J. M., Zhou, Y., Li, G. Y., et al. (2015). MicroRNA-155 regulates interferon- $\gamma$ production in natural killer cells via Tim-3 signalling in chronic hepatitis C virus infection. Immunology 145 , 485-497. doi: 10.1111/imm.12463

Chim, C. S., Wong, K. Y., Leung, C. Y., Chung, L. P., Hui, P. K., Chan, S. Y., et al. (2011). Epigenetic inactivation of the hsa-miR203 in haematological malignancies. J. Cell. Mol. Med. 15, 2760-2767. doi: 10.1111/j.1582-4934.2011.01274.x

Chim, C. S., Wong, K. Y., Qi, Y., Loong, F., Lam, W. L., Wong, L. G., et al. (2010). Epigenetic inactivation of the miR-34a in hematological malignancies. Carcinogenesis 31, 745-750. doi: 10.1093/carcin/bgq033

Chiossone, L., Vienne, M., Kerdiles, Y. M., and Vivier, E. (2017). Natural killer cell immunotherapies against cancer: checkpoint inhibitors and more. Semin. Immunol. 31, 55-63. doi: 10.1016/j.smim.2017.08.003 
Cichocki, F., Felices, M., McCullar, V., Presnell, S. R., Al-Attar, A., Lutz, C. T., et al. (2011). Cutting edge: microRNA-181 promotes human NK cell development by regulating Notch signaling. J. Immunol. 187, 6171-6175. doi: 10.4049/jimmunol.1100835

Cioffi, M., Trabulo, S. M., Vallespinos, M., Raj, D., Kheir, T. B., Lin, M.-L., et al. (2017). The miR-25-93-106b cluster regulates tumor metastasis and immune evasion via modulation of CXCL12 and PD-L1. Oncotarget 8: 21609-25. doi: 10.18632/oncotarget.15450

Cobb, B. S., Hertweck, A., Smith, J., O'Connor, E., Graf, D., Cook, T., et al. (2006). A role for Dicer in immune regulation. J. Exp. Med. 203, 2519-2527. doi: 10.1084/jem.20061692

Cortez, V. S., and Colonna, M. (2016). Diversity and function of group 1 innate lymphoid cells. Immunol. Lett. 179, 19-24. doi: 10.1016/j.imlet.2016.07.005

Cosman, D., Fanger, N., Borges, L., Kubin, M., Chin, W., Peterson, L., et al. (1997). A novel immunoglobulin superfamily receptor for cellular and viral MHC class I molecules. Immunity 7, 273-282. doi: 10.1016/S1074-7613(00)80529-4

Costello, R. T., Sivori, S., Marcenaro, E., Lafage-Pochitaloff, M., Mozziconacci, M.-J., Reviron, D., et al. (2002). Defective expression and function of natural killer cell-triggering receptors in patients with acute myeloid leukemia. Blood 99, 3661-3667. doi: 10.1182/blood.V99.10.3661

Cron, M. A., Maillard, S., Truffault, F., Gualeni, A. V., Gloghini, A., Fadel, E., et al. (2019). Causes and consequences of miR-150-5p dysregulation in myasthenia gravis. Front. Immunol. 10:539. doi: 10.3389/fimmu.2019.00539

Cutrona, G., Matis, S., Colombo, M., Massucco, C., Baio, G., Valdora, F., et al. (2017). Effects of miRNA-15 and miRNA-16 expression replacement in chronic lymphocytic leukemia: implication for therapy. Leukemia 31, 1894-1904. doi: 10.1038/leu.2016.394

Dallaire, A., and Simard, M. J. (2016). The implication of microRNAs and endosiRNAs in animal germline and early development. Dev. Biol. 416, 18-25. doi: 10.1016/j.ydbio.2016.06.007

Del Zotto, G., Marcenaro, E., Vacca, P., Sivori, S., Pende, D., Della Chiesa, M., et al. (2017). Markers and function of human NK cells in normal and pathological conditions. Cytometry B Clin. Cytom. 92, 100-114. doi: 10.1002/cyto.b.21508

Della Chiesa, M., Marcenaro, E., Sivori, S., Carlomagno, S., Pesce, S., and Moretta, A. (2014). Human NK cell response to pathogens. Semin. Immunol. 26, 152-160. doi: 10.1016/j.smim.2014.02.001

Della Chiesa, M., Pesce, S., Muccio, L., Carlomagno, S., Sivori, S., Moretta, A., et al. (2016). Features of memory-like and PD-1+ human NK cell subsets. Front. Immunol. 7:351. doi: 10.3389/fimmu.2016.00351

Di Santo, J. P. (2006). Natural killer cell developmental pathways: a question of Balance. Annu. Rev. Immunol. 24, 257-286. doi: 10.1146/annurev.immunol.24.021605.090700

Di Vito, C., Mikulak, J., Zaghi, E., Pesce, S., Marcenaro, E., and Mavilio, D. (2019). NK cells to cure cancer. Semin. Immunol. 41:101272. doi: 10.1016/j.smim.2019.03.004

Diederichs, S., and Haber, D. A. (2007). Dual role for argonautes in microRNA processing and posttranscriptional regulation of microRNA expression. Cell 131, 1097-1108. doi: 10.1016/j.cell.2007.10.032

Donatelli, S. S., Zhou, J.-M., Gilvary, D. L., Eksioglu, E. A., Chen, X., Cress, W. D., et al. (2014). TGF- $\beta$-inducible microRNA-183 silences tumorassociated natural killer cells. Proc. Natl. Acad. Sci. U.S.A. 111, 4203-4208. doi: 10.1073/pnas.1319269111

El Sobky, S. A., El-Ekiaby, N. M., Mekky, R. Y., Elemam, N. M., Mohey Eldin, M. A., El-sayed, M., et al. (2016). Contradicting roles of miR-182 in both NK cells and their host target hepatocytes in HCV. Immunol. Lett. 169, 52-60. doi: 10.1016/j.imlet.2015.10.013

Elemam, N. M., Mekky, R. Y., El-Ekiaby, N. M., El Sobky, S. A., El Din, M. A. M., Esmat, G., et al. (2015). Repressing PU.1 by miR-29a* in NK cells of HCV patients, diminishes its cytolytic effect on HCV infected cell models. Hum. Immunol. 76, 687-694. doi: 10.1016/j.humimm.2015.09.021

Espinoza, J. L., Takami, A., Yoshioka, K., Nakata, K., Sato, T., Kasahara, Y., et al. (2012). Human microRNA-1245 down-regulates the NKG2D receptor in natural killer cells and impairs NKG2D-mediated functions. Haematologica 97, 1295-1303. doi: 10.3324/haematol.2011.058529

Fabbri, M. (2020). Natural killer cell-derived vesicular miRNAs: a new anticancer approach? Cancer Res. 80, 17-22. doi: 10.1158/0008-5472.CAN-19-1450

Farag, S. S., and Caligiuri, M. A. (2006). Human natural killer cell development and biology. Blood Rev. 20, 123-137. doi: 10.1016/j.blre.2005.10.001
Fedeli, M., Napolitano, A., Wong, M. P. M., Marcais, A., de Lalla, C., Colucci, F., et al. (2009). Dicer-dependent microRNA pathway controls invariant NKT cell development. J. Immunol. 183, 2506-2512. doi: 10.4049/jimmunol.0901361

Fehniger, T. A., Wylie, T., Germino, E., Leong, J. W., Magrini, V. J., Koul, S., et al. (2010). Next-generation sequencing identifies the natural killer cell microRNA transcriptome. Genome Res. 20, 1590-1604. doi: 10.1101/gr.107995.110

Filipowicz, W., Bhattacharyya, S. N., and Sonenberg, N. (2008). Mechanisms of post-transcriptional regulation by microRNAs: are the answers in sight? Nat. Rev. Genet. 9, 102-114. doi: 10.1038/nrg2290

Freud, A. G., and Caligiuri, M. A. (2006). Human natural killer cell development. Immunol. Rev. 214, 56-72. doi: 10.1111/j.1600-065X.2006.00451.X

Freud, A. G., Mundy-Bosse, B. L., Yu, J., and Caligiuri, M. A. (2017). The broad spectrum of human natural killer cell diversity. Immunity 47, 820-833. doi: 10.1016/j.immuni.2017.10.008

Gao, F., Zhao, Z.-L., Zhao, W.-T., Fan, Q.-R., Wang, S.-C., Li, J., et al. (2013). miR-9 modulates the expression of interferon-regulated genes and MHC class I molecules in human nasopharyngeal carcinoma cells. Biochem. Biophys. Res. Commun. 431, 610-616. doi: 10.1016/j.bbrc.2012.12.097

Gao, L., Guo, Q., Li, X., Yang, X., Ni, H., Wang, T., et al. (2019). MiR-873/PD-L1 axis regulates the stemness of breast cancer cells. EBioMedicine 41, 395-407. doi: 10.1016/j.ebiom.2019.02.034

Gracias, D. T., Stelekati, E., Hope, J. L., Boesteanu, A. C., Doering, T. A., Norton, J., et al. (2013). The microRNA miR-155 controls CD8(+) T cell responses by regulating interferon signaling. Nat. Immunol. 14, 593-602. doi: 10.1038/ni.2576

Gregory, R. I., Yan, K.-P., Amuthan, G., Chendrimada, T., Doratotaj, B., Cooch, N., et al. (2004). The microprocessor complex mediates the genesis of microRNAs. Nature 432, 235-240. doi: 10.1038/nature03120

$\mathrm{Gu}, \mathrm{S}$., and Kay, M. A. (2010). How do miRNAs mediate translational repression? Silence 1:11. doi: 10.1186/1758-907X-1-11

Guo, H.-Q., Huang, G.-L., Guo, C.-C., Pu, X.-X., and Lin, T.-Y. (2010). Diagnostic and prognostic value of circulating miR-221 for extranodal natural killer/T-cell lymphoma. Dis. Markers 29, 251-258. doi: 10.1155/2010/ 474692

Guo, W., Tan, W., Liu, S., Huang, X., Lin, J., Liang, R., et al. (2015). MiR-570 inhibited the cell proliferation and invasion through directly targeting B7-H1 in hepatocellular carcinoma. Tumor Biol. 36, 9049-9057. doi: $10.1007 /$ s13277-015-3644-3

Hallner, A., Bernson, E., Hussein, B. A., Ewald Sander, F., Brune, M., Aurelius, J., et al. (2019). The HLA-B-21 dimorphism impacts on NK cell education and clinical outcome of immunotherapy in acute myeloid leukemia. Blood 133, 1479-1488. doi: 10.1182/blood-2018-09-874990

Han, B., Mao, F.-Y., Zhao, Y.-L., Lv, Y.-P., Teng, Y.-S., Duan, M., et al. (2018). Altered NKp30, NKp46, NKG2D, and DNAM-1 expression on circulating NK cells is associated with tumor progression in human gastric cancer. J. Immunol. Res. 2018:6248590. doi: 10.1155/2018/6248590

Hart, O. M., Athie-Morales, V., O'Connor, G. M., and Gardiner, C. M. (2005). TLR7/8-mediated activation of human NK cells results in accessory cell-dependent IFN- $\gamma$ production. J. Immunol. 175, 1636-1642. doi: 10.4049/jimmunol.175.3.1636

He, S., Chu, J., Wu, L.-C., Mao, H., Peng, Y., Alvarez-Breckenridge, C. A., et al. (2013). MicroRNAs activate natural killer cells through Toll-like receptor signaling. Blood 121, 4663-4671. doi: 10.1182/blood-2012-07-441360

Horsburgh, S., Fullard, N., Roger, M., Degnan, A., Todryk, S., Przyborski, S. et al. (2017). MicroRNAs in the skin: role in development, homoeostasis and regeneration. Clin. Sci. 131, 1923-1940. doi: 10.1042/CS20170039.

Hsu, J., Hodgins, J. J., Marathe, M., Nicolai, C. J., Bourgeois-Daigneault, M.-C., Trevino, T. N., et al. (2018). Contribution of NK cells to immunotherapy mediated by PD-1/PD-L1 blockade. J. Clin. Invest. 128, 4654-4668. doi: $10.1172 /$ JCI99317

Hua, M., Li, J., Wang, C., Shao, L., Hou, M., Peng, J., et al. (2019). Aberrant expression of microRNA in CD4+ cells contributes to Th17/Treg imbalance in primary immune thrombocytopenia. Thromb. Res. 177, 70-78. doi: 10.1016/j.thromres.2019.03.005

Huang, H., Fan, L., Zhan, R., Wu, S., and Niu, W. (2016). Expression of microRNA-10a, microRNA-342-3p and their predicted target gene TIAM1 in extranodal NK/T-cell lymphoma, nasal type. Oncol. Lett. 11, 345-351. doi: $10.3892 / \mathrm{ol} .2015 .3831$ 
Ichimura, A., Ruike, Y., Terasawa, K., Shimizu, K., and Tsujimoto, G. (2010). MicroRNA-34a inhibits cell proliferation by repressing mitogen-activated protein kinase kinase 1 during megakaryocytic differentiation of K562 cells. Mol. Pharmacol. 77, 1016-1024. doi: 10.1124/mol.109.063321

Ichiyama, K., Gonzalez-Martin, A., Kim, B.-S., Jin, H. Y., Jin, W., Xu, W., et al. (2016). The microRNA-183-96-182 cluster promotes $\mathrm{T}$ helper 17 cell pathogenicity by negatively regulating transcription factor Foxol expression. Immunity 44, 1284-1298. doi: 10.1016/j.immuni.2016.05.015

Ivanova, E., Bozhilova, R., Kaneva, R., and Milanova, V. (2018). The dysregulation of microRNAs and the role of stress in the pathogenesis of mental disorders. Curr. Top. Med. Chem. 18, 1893-1907. doi: $10.2174 / 1568026619666181130135253$

Jia, L., Xi, Q., Wang, H., Zhang, Z., Liu, H., Cheng, Y., et al. (2017). miR-142$5 \mathrm{p}$ regulates tumor cell PD-L1 expression and enhances anti-tumor immunity. Biochem. Biophys. Res. Commun. 488, 425-431. doi: 10.1016/j.bbrc.2017.05.074

Johnson, J. L. (2019). Elucidating the contributory role of microRNA to cardiovascular diseases (a review). Vascul. Pharmacol. 114, 31-48. doi: 10.1016/j.vph.2018.10.010

Kao, S. C., Cheng, Y. Y., Williams, M., Kirschner, M. B., Madore, J., Lum, T., et al. (2017). Tumor suppressor microRNAs contribute to the regulation of PD-L1 expression in malignant pleural mesothelioma. J. Thoracic Oncol. 12, 1421-1433. doi: 10.1016/j.jtho.2017.05.024

Kim, N., Kim, M., Yun, S., Doh, J., Greenberg, P. D., Kim, T.-D., et al. (2014). MicroRNA-150 regulates the cytotoxicity of natural killers by targeting perforin-1. J. Allergy Clin. Immunol. 134, 195-203. doi: 10.1016/j.jaci.2014.02.018

Kim, T.-D., Lee, S. U., Yun, S., Sun, H.-N., Lee, S. H., Kim, J. W., et al. (2011). Human microRNA-27a* targets Prf1 and GzmB expression to regulate NK-cell cytotoxicity. Blood 118, 5476-5486. doi: 10.1182/blood-2011-04-347526

Kishikawa, T., Otsuka, M., Yoshikawa, T., Ohno, M., Takata, A., Shibata, C., et al. (2013). Regulation of the expression of the liver cancer susceptibility gene MICA by microRNAs. Sci. Rep. 3:2739. doi: 10.1038/srep02739

Kohrt, H. E., Thielens, A., Marabelle, A., Sagiv-Barfi, I., Sola, C., Chanuc, F., et al. (2014). Anti-KIR antibody enhancement of anti-lymphoma activity of natural killer cells as monotherapy and in combination with anti-CD20 antibodies. Blood 123, 678-686. doi: 10.1182/blood-2013-08-519199

Komabayashi, Y., Kishibe, K., Nagato, T., Ueda, S., Takahara, M., and Harabuchi, Y. (2014). Downregulation of miR-15a due to LMP1 promotes cell proliferation and predicts poor prognosis in nasal NK/T-cell lymphoma. Am. J. Hematol. 89, 25-33. doi: 10.1002/ajh.23570

Koralov, S. B., Muljo, S. A., Galler, G. R., Krek, A., Chakraborty, T., Kanellopoulou, C., et al. (2008). Dicer ablation affects antibody diversity and cell survival in the B lymphocyte lineage. Cell 132, 860-874. doi: 10.1016/j.cell.2008.02.020

Li, Q., Johnston, N., Zheng, X., Wang, H., Zhang, X., Gao, D., et al. (2016). miR-28 modulates exhaustive differentiation of $\mathrm{T}$ cells through silencing programmed cell death-1 and regulating cytokine secretion. Oncotarget 7, 53735-50. doi: 10.18632/oncotarget.10731

Liston, A., Lu, L.-F., O'Carroll, D., Tarakhovsky, A., and Rudensky, A. Y. (2008). Dicer-dependent microRNA pathway safeguards regulatory $\mathrm{T}$ cell function. $J$. Exp. Med. 205, 1993-2004. doi: 10.1084/jem.20081062

Liu, B., Li, J., and Cairns, M. J. (2014). Identifying miRNAs, targets and functions. Brief Bioinformatics 15, 1-19. doi: 10.1093/bib/bbs075

Liu, B., Li, J., Tsykin, A., Liu, L., Gaur, A. B., and Goodall, G. J. (2009). Exploring complex miRNA-mRNA interactions with Bayesian networks by splittingaveraging strategy. BMC Bioinformatics 10:408. doi: 10.1186/1471-2105-10-408

Liu, X., Wang, Y., Sun, Q., Yan, J., Huang, J., Zhu, S., et al. (2012). Identification of microRNA transcriptome involved in human natural killer cell activation. Immunol. Lett. 143, 208-217. doi: 10.1016/j.imlet.2012.02.014

Lugini, L., Cecchetti, S., Huber, V., Luciani, F., Macchia, G., Spadaro, F., et al. (2012). Immune surveillance properties of human NK cell-derived exosomes. J. Immunol. 189, 2833-2842. doi: 10.4049/jimmunol.1101988

Macfarlane, L.-A., and Murphy, P. R. (2010). MicroRNA: biogenesis, function and role in cancer. Curr. Genomics 11, 537-561. doi: 10.2174/138920210793175895

Mandelboim, O., Pazmany, L., Davis, D. M., Valés-Gómez, M., Reyburn, H. T., Rybalov, B., et al. (1997). Multiple receptors for HLA-G on human natural killer cells. Proc. Natl. Acad. Sci. U.S.A. 94, 14666-14670. doi: $10.1073 /$ pnas.94.26.14666
Marcenaro, E., Della Chiesa, M., Bellora, F., Parolini, S., Millo, R., Moretta, L., et al (2005a). IL-12 or IL-4 prime human NK cells to mediate functionally divergent interactions with dendritic cells or tumors. J. Immunol. 174, 3992-3998. doi: 10.4049/jimmunol.174.7.3992

Marcenaro, E., Dondero, A., and Moretta, A. (2006). Multi-directional crossregulation of NK cell function during innate immune responses. Transplant. Immunol. 17, 16-19. doi: 10.1016/j.trim.2006.09.019

Marcenaro, E., Ferranti, B., Falco, M., Moretta, L., and Moretta, A. (2008). Human NK cells directly recognize Mycobacterium bovis via TLR2 and acquire the ability to kill monocyte-derived DC. Int. Immunol. 20, 1155-1167. doi: 10.1093/intimm/dxn073

Marcenaro, E., Ferranti, B., and Moretta, A. (2005b). NK-DC interaction: on the usefulness of auto-aggression. Autoimmun. Rev. 4, 520-525. doi: 10.1016/j.autrev.2005.04.015

Marcenaro, E., Notarangelo, L. D., Orange, J. S., and Vivier, E. (2017). Editorial: NK cell subsets in health and disease: new developments. Front. Immunol. 8:1363. doi: 10.3389/978-2-88945-350-4

Mariotti, F. R., Petrini, S., Ingegnere, T., Tumino, N., Besi, F., Scordamaglia, F., et al. (2019). PD-1 in human NK cells: evidence of cytoplasmic mRNA and protein expression. Oncoimmunology 8:1557030. doi: 10.1080/2162402X.2018.1557030

Moretta, A., Bottino, C., Vitale, M., Pende, D., Biassoni, R., Mingari, M. C., et al. (1996). Receptors for HLA class-i molecules in human natural killer cells. Annu. Rev. Immunol. 14, 619-648. doi: 10.1146/annurev.immunol.14.1.619

Moretta, A., Bottino, C., Vitale, M., Pende, D., Cantoni, C., Mingari, M. C., et al. (2001). Activating receptors and coreceptors involved in human natural killer cell-mediated cytolysis. Annu. Rev. Immunol. 19, 197-223. doi: 10.1146/annurev.immunol.19.1.197

Moretta, L., Bottino, C., Pende, D., Vitale, M., Mingari, M., and Moretta, A. (2004). Different checkpoints in human NK-cell activation. Trends Immunol. 25, 670-676. doi: 10.1016/j.it.2004.09.008

Moretta, L., Ferlazzo, G., Bottino, C., Vitale, M., Pende, D., Mingari, M. C., et al. (2006). Effector and regulatory events during natural killer-dendritic cell interactions. Immunol. Rev. 214, 219-228. doi: 10.1111/j.1600-065X.2006.00450.x

Mori, M. A., Ludwig, R. G., Garcia-Martin, R., Brandão, B. B., and Kahn, C. R. (2019). Extracellular miRNAs: from biomarkers to mediators of physiology and disease. Cell Metab. 30, 656-673 doi: 10.1016/j.cmet.2019.07.011

Muljo, S. A., Ansel, K. M., Kanellopoulou, C., Livingston, D. M., Rao, A., and Rajewsky, K. (2005). Aberrant T cell differentiation in the absence of Dicer. J. Exp. Med. 202, 261-269. doi: 10.1084/jem.20050678

Ng, S.-B., Yan, J., Huang, G., Selvarajan, V., Tay, J. L.-S., Lin, B., et al. (2011). Dysregulated microRNAs affect pathways and targets of biologic relevance in nasal-type natural killer/T-cell lymphoma. Blood 118, 4919-4929. doi: 10.1182/blood-2011-07-364224

Ni, F., Guo, C., Sun, R., Fu, B., Yang, Y., Wu, L., et al. (2015). MicroRNA transcriptomes of distinct human NK cell populations identify miR-362$5 \mathrm{p}$ as an essential regulator of NK cell function. Sci. Rep. 5:9993. doi: $10.1038 /$ srep09993

Nutalai, R., Gaudieri, S., Jumnainsong, A., and Leelayuwat, C. (2019). Regulation of KIR3DL3 expression via mirna. Genes 10:603. doi: 10.3390/genes10080603

Omar, H. A., El-Serafi, A. T., Hersi, F., Arafa, E. A., Zaher, D. M., Madkour, M., et al. (2019). Immunomodulatory MicroRNAs in cancer: targeting immune checkpoints and the tumor microenvironment. FEBS J. 286, 3540-3557. doi: $10.1111 /$ febs. 15000

Parodi, M., Pedrazzi, M., Cantoni, C., Averna, M., Patrone, M., Cavaletto, M., et al. (2015). Natural killer (NK)/melanoma cell interaction induces NKmediated release of chemotactic High Mobility Group Box-1 (HMGB1) capable of amplifying NK cell recruitment. Oncoimmunology 4:e1052353. doi: 10.1080/2162402X.2015.1052353

Parolini, I., Federici, C., Raggi, C., Lugini, L., Palleschi, S., De Milito, A., et al. (2009). Microenvironmental $\mathrm{pH}$ is a key factor for exosome traffic in tumor cells. J. Biol. Chem. 284, 34211-34222. doi: 10.1074/jbc.M109.041152

Peng, Y., and Croce, C. M. (2016). The role of MicroRNAs in human cancer. Signal. Transduct. Target Ther. 1:15004. doi: 10.1038/sigtrans.2015.4

Pesce, S., Belgrano, V., Greppi, M., Carlomagno, S., Squillario, M., Barla, A., et al. (2019a). Different features of tumor-associated NK cells in patients with 
low-grade or high-grade peritoneal carcinomatosis. Front. Immunol. 10:1963. doi: 10.3389/fimmu.2019.01963

Pesce, S., Greppi, M., Grossi, F., Del Zotto, G., Moretta, L., Sivori, S., et al. (2019b). PD/1-PD-Ls checkpoint: insight on the potential role of NK cells. Front. Immunol. 10:1242. doi: 10.3389/fimmu.2019.01242

Pesce, S., Greppi, M., Tabellini, G., Rampinelli, F., Parolini, S., Olive, D., et al. (2017a). Identification of a subset of human natural killer cells expressing high levels of programmed death 1: A phenotypic and functional characterization. J. Allergy Clin. Immunol. 139, 335-346.e3. doi: 10.1016/j.jaci.2016.04.025

Pesce, S., Moretta, L., Moretta, A., and Marcenaro, E. (2016). Human NK cell subsets redistribution in pathological conditions: a Role for CCR7 receptor. Front. Immunol. 7:414. doi: 10.3389/fimmu.2016.00414

Pesce, S., Squillario, M., Greppi, M., Loiacono, F., Moretta, L., Moretta, A., et al. (2018). New miRNA signature heralds human NK cell subsets at different maturation steps: involvement of miR-146a-5p in the regulation of KIR expression. Front. Immunol. 9:2360. doi: 10.3389/fimmu.2018.02360

Pesce, S., Tabellini, G., Cantoni, C., Patrizi, O., Coltrini, D., Rampinelli, F., et al. (2015). B7-H6-mediated downregulation of NKp30 in NK cells contributes to ovarian carcinoma immune escape. OncoImmunology 4:e1001224. doi: 10.1080/2162402X.2014.1001224

Pesce, S., Thoren, F. B., Cantoni, C., Prato, C., Moretta, L., Moretta, A., et al. (2017b). The innate immune cross talk between NK cells and eosinophils is regulated by the interaction of natural cytotoxicity receptors with eosinophil surface ligands. Front. Immunol. 8:510. doi: 10.3389/fimmu.2017.00510

Petty, R. D., McCarthy, N. E., Le Dieu, R., and Kerr, J. R. (2016). MicroRNAs hsa-miR-99b, hsa-miR-330, hsa-miR-126 and hsa-miR-30c: potential diagnostic biomarkers in natural killer (NK) cells of patients with chronic fatigue syndrome (CFS)/myalgic encephalomyelitis (ME). PLoS ONE 11:e0150904. doi: 10.1371/journal.pone.0150904

Poznanski, S. M., and Ashkar, A. A. (2019). What defines NK cell functional fate: phenotype or metabolism? Front. Immunol. 10:1414. doi: 10.3389/fimmu.2019.01414

Riise, R. E., Bernson, E., Aurelius, J., Martner, A., Pesce, S., Della Chiesa, M., et al. (2015). TLR-stimulated neutrophils instruct NK cells to trigger dendritic cell maturation and promote adaptive T cell responses. J. Immunol. 195, 1121-1128. doi: 10.4049/jimmunol.1500709

Romagnani, C., Juelke, K., Falco, M., Morandi, B., D’Agostino, A., Costa, R., et al. (2007). CD56brightCD16- killer Ig-like receptor- NK cells display longer telomeres and acquire features of CD56dim NK cells upon activation. J. Immunol. 178, 4947-4955. doi: 10.4049/jimmunol.178.8.4947

Romagne, F., Andre, P., Spee, P., Zahn, S., Anfossi, N., Gauthier, L., et al. (2009). Preclinical characterization of 1-7F9, a novel human anti-KIR receptor therapeutic antibody that augments natural killer-mediated killing of tumor cells. Blood 114, 2667-2677. doi: 10.1182/blood-2009-02-206532

Romero, A. I., Thorén, F. B., Brune, M., and Hellstrand, K. (2006). NKp46 and NKG2D receptor expression in NK cells with CD56dim and CD56bright phenotype: regulation by histamine and reactive oxygen species. $\mathrm{Br}$. J. Haematol. 132, 91-98. doi: 10.1111/j.1365-2141.2005.05842.x

Rouas, R., Merimi, M., Najar, M., El Zein, N., Fayyad-Kazan, M., Berehab, M., et al. (2019). Human CD8+ CD25 + CD127 low regulatory T cells: microRNA signature and impact on TGF- $\beta$ and IL-10 expression. J. Cell. Physiol. 234, 17459-17472. doi: 10.1002/jcp.28367

Saki, N., Abroun, S., Soleimani, M., Hajizamani, S., Shahjahani, M., Kast, R. E., et al. (2015). Involvement of microRNA in T-cell differentiation and malignancy. Int. J. Hematol. Oncol. Stem Cell Res. 9, 33-49.

Sanchez-Correa, B., Valhondo, I., Hassouneh, F., Lopez-Sejas, N., Pera, A., Bergua, J. M., et al. (2019). DNAM-1 and the TIGIT/PVRIG/TACTILE axis: novel immune checkpoints for natural killer cell-based cancer immunotherapy. Cancers 11:E877. doi: 10.3390/cancers11060877

Seliger, B. (2016). Role of microRNAs on HLA-G expression in human tumors. Human Immunol. 77, 760-763. doi: 10.1016/j.humimm.2016.04.006

Sivori, S., Falco, M., Della Chiesa, M., Carlomagno, S., Vitale, M., Moretta, L., et al. (2004). CpG and double-stranded RNA trigger human NK cells by Toll-like receptors: induction of cytokine release and cytotoxicity against tumors and dendritic cells. Proc. Natl. Acad. Sci. U.S.A. 101, 10116-10121. doi: 10.1073/pnas.0403744101

Stittrich, A.-B., Haftmann, C., Sgouroudis, E., Kühl, A. A., Hegazy, A. N., Panse, I., et al. (2010). The microRNA miR-182 is induced by IL-2 and promotes clonal expansion of activated helper T lymphocytes. Nat. Immunol. 11, 1057-1062. doi: 10.1038/ni.1945

Sullivan, R. P., Fogel, L. A., Leong, J. W., Schneider, S. E., Wong, R., Romee, R., et al. (2013). MicroRNA-155 tunes both the threshold and extent of NK cell activation via targeting of multiple signaling pathways. J. Immunol. 191, 5904-5913. doi: 10.4049/jimmunol.1301950

Sullivan, R. P., Leong, J. W., Schneider, S. E., Keppel, C. R., Germino, E., French, A. R., et al. (2012). MicroRNA-deficient NK cells exhibit decreased survival but enhanced function. J. Immunol. 188, 3019-3030. doi: 10.4049/jimmunol.1102294

Tao, Z., Xu, S., Ruan, H., Wang, T., Song, W., Qian, L., et al. (2018). MiR195/-16 family enhances radiotherapy via $\mathrm{T}$ cell activation in the tumor microenvironment by blocking the PD-L1 immune checkpoint. Cell. Physiol. Biochem. 48, 801-814. doi: 10.1159/000491909

Tinker, A. V., Hirte, H. W., Provencher, D., Butler, M., Ritter, H., Tu, D., et al. (2019). Dose-ranging and cohort-expansion study of monalizumab (IPH2201) in patients with advanced gynecologic malignancies: a trial of the canadian cancer trials group (CCTG): IND221. Clin. Cancer Res. 25, 6052-6060 doi: 10.1158/1078-0432.CCR-19-0298

Trinh, T. L., Kandell, W. M., Donatelli, S. S., Tu, N., Tejera, M. M., Gilvary, D. L., et al. (2019). Immune evasion by TGF $\beta$-induced miR-183 repression of MICA/B expression in human lung tumor cells. OncoImmunology 8:e1557372. doi: 10.1080/2162402X.2018.1557372

Trotta, R., Chen, L., Ciarlariello, D., Josyula, S., Mao, C., Costinean, S., et al. (2012). miR-155 regulates IFN- $\gamma$ production in natural killer cells. Blood 119, 3478-3485. doi: 10.1182/blood-2011-12-398099

Tsujimoto, H., Uchida, T., Efron, P. A., Scumpia, P. O., Verma, A., Matsumoto, T., et al. (2005). Flagellin enhances NK cell proliferation and activation directly and through dendritic cell-NK cell interactions. J. Leukoc. Biol. 78, 888-897. doi: 10.1189/jlb.0105051

Vey, N., Bourhis, J.-H., Boissel, N., Bordessoule, D., Prebet, T., Charbonnier, A., et al. (2012). A phase 1 trial of the anti-inhibitory KIR mAb IPH2101 for AML in complete remission. Blood 120, 4317-4323. doi: 10.1182/blood-2012-06-437558

Vey, N., Karlin, L., Sadot-Lebouvier, S., Broussais, F., Berton-Rigaud, D., Rey, J., et al. (2018). A phase 1 study of lirilumab (antibody against killer immunoglobulin-like receptor antibody KIR2D; IPH2102) in patients with solid tumors and hematologic malignancies. Oncotarget 9, 17675-17688. doi: $10.18632 /$ oncotarget.24832

Vivier, E., Raulet, D. H., Moretta, A., Caligiuri, M. A., Zitvogel, L., Lanier, L. L., et al. (2011). Innate or adaptive immunity? The example of natural killer cells. Science 331, 44-49. doi: 10.1126/science. 1198687

Voo, K. S., Bover, L., Harline, M. L., Weng, J., Sugimoto, N., and Liu, Y.-J. (2014). Targeting of TLRs inhibits $\mathrm{CD} 4{ }^{+}$regulatory $\mathrm{T}$ cell function and activates lymphocytes in human peripheral blood mononuclear cells. J. Immunol. 193, 627-634. doi: 10.4049/jimmunol.1203334

Wang, H., Chen, S., and Ye, X. (2019). Cocktail strategy based on NK cell-derived exosomes and their biomimetic nanoparticles for dual tumor therapy. Cancers 11:1560. doi: 10.3390/cancers11101560

Wang, H., Zhang, Y., Wu, X., Wang, Y., Cui, H., Li, X., et al. (2018). Regulation of human natural killer cell IFN- $\gamma$ production by microRNA$146 \mathrm{a}$ via targeting the NF- $\mathrm{B}$ signaling pathway. Front. Immunol. 9:293. doi: 10.3389/fimmu.2018.00293

Wang, L., Zhang, H., and Lei, D. (2019). microRNA-146a promotes growth of acute leukemia cells by downregulating ciliary neurotrophic factor receptor and activating JAK2/STAT3 signaling. Yonsei Med. J. 60, 924-934. doi: $10.3349 / y m j .2019 .60 .10 .924$

Wang, P., Gu, Y., Zhang, Q., Han, Y., Hou, J., Lin, L., et al. (2012). Identification of resting and type I IFN-activated human NK cell miRNomes reveals microRNA378 and microRNA-30e as negative regulators of NK cell cytotoxicity. J. Immunol. 189, 211-221. doi: 10.4049/jimmunol.1200609

Wang, Q., Lin, W., Tang, X., Li, S., Guo, L., Lin, Y., et al. (2017). The roles of microRNAs in regulating the expression of PD-1/PD-L1 immune checkpoint. Int. J. Mol. Sci. 18:2540. doi: 10.3390/ijms18122540

Wang, X., Li, J., Dong, K., Lin, F., Long, M., Ouyang, Y., et al. (2015). Tumor suppressor miR-34a targets PD-L1 and functions as a potential immunotherapeutic target in acute myeloid leukemia. Cell. Signal. 27, 443-452. doi: 10.1016/j.cellsig.2014.12.003 
Watanabe, A., Tagawa, H., Yamashita, J., Teshima, K., Nara, M., Iwamoto, K., et al. (2011). The role of microRNA-150 as a tumor suppressor in malignant lymphoma. Leukemia 25, 1324-1334. doi: 10.1038/leu.2011.81

Wei, J., Nduom, E. K., Kong, L. -Y., Hashimoto, Y., Xu, S., Gabrusiewicz, K., et al. (2016). MiR-138 exerts anti-glioma efficacy by targeting immune checkpoints. Neuro. Oncol. 18, 639-648. doi: 10.1093/neuonc/nov292

Winter, S. J., and Krueger, A. (2019). Development of unconventional $\mathrm{T}$ cells controlled by MicroRNA. Front. Immunol. 10:2520. doi: 10.3389/fimmu.2019.02520

Xie, J., Liu, M., Li, Y., Nie, Y., Mi, Q., and Zhao, S. (2014). Ovarian tumor-associated microRNA-20a decreases natural killer cell cytotoxicity by downregulating MICA/B expression. Cell. Mol. Immunol. 11, 495-502. doi: $10.1038 / \mathrm{cmi} .2014 .30$

Xu, D., Han, Q., Hou, Z., Zhang, C., and Zhang, J. (2017). miR-146a negatively regulates NK cell functions via STAT1 signaling. Cell. Mol. Immunol. 14, 712-720. doi: 10.1038/cmi.2015.113

Xu, S., Tao, Z., Hai, B., Liang, H., Shi, Y., Wang, T., et al. (2016). miR424(322) reverses chemoresistance via T-cell immune response activation by blocking the PD-L1 immune checkpoint. Nat. Commun. 7:11406. doi: 10.1038/ncomms11406

Yamanaka, Y., Tagawa, H., Takahashi, N., Watanabe, A., Guo, Y.-M., Iwamoto, K., et al. (2009). Aberrant overexpression of microRNAs activate AKT signaling via down-regulation of tumor suppressors in natural killer-cell lymphoma/leukemia. Blood 114, 3265-3275. doi: 10.1182/blood-2009-06-222794

Yang, P., Ni, F., Deng, R.-Q., Qiang, G., Zhao, H., Yang, M.-Z., et al. (2015). MiR$362-5 p$ promotes the malignancy of chronic myelocytic leukaemia via downregulation of GADD45 $\alpha$. Mol. Cancer 14:190. doi: 10.1186/s12943-015-0465-3

Yang, Q., Li, J., Hu, Y., Tang, X., Yu, L., Dong, L., et al. (2019). MiR-218-5p suppresses the killing effect of natural killer cell to lung adenocarcinoma by targeting SHMT1. Yonsei Med. J. 60, 500-508. doi: 10.3349/ymj.2019.60.6.500

Yee, D., Shah, K. M., Coles, M. C., Sharp, T. V., and Lagos, D. (2017). MicroRNA-155 induction via TNF- $\alpha$ and IFN- $\gamma$ suppresses expression of programmed death ligand-1 (PD-L1) in human primary cells. J. Biol. Chem. 292, 20683-20693. doi: 10.1074/jbc.M117.809053

Yi, R., Qin, Y., Macara, I. G., and Cullen, B. R. (2003). Exportin-5 mediates the nuclear export of pre-microRNAs and short hairpin RNAs. Genes Dev. 17, 3011-3016. doi: 10.1101/gad.1158803
Yu, J., Mao, H. C., Wei, M., Hughes, T., Zhang, J., Park, I., et al. (2010). CD94 surface density identifies a functional intermediary between the CD56bright and CD56dim human NK-cell subsets. Blood 115, 274-281. doi: 10.1182/blood-2009-04-215491

Yun, S., Lee, S. U., Kim, J. M., Lee, H.-J., Song, H. Y., Kim, Y. K., et al. (2014). Integrated mRNA-microRNA profiling of human NK cell differentiation identifies MiR-583 as a negative regulator of IL2R $\gamma$ expression. PLoS ONE 9:e108913. doi: 10.1371/journal.pone.0108913

Zaghi, E., Calvi, M., Marcenaro, E., Mavilio, D., and Di Vito, C. (2019). Targeting NKG2A to elucidate natural killer cell ontogenesis and to develop novel immune-therapeutic strategies in cancer therapy. J. Leukoc. Biol. 105, 1243-1251. doi: 10.1002/JLB.MR0718-300R

Zawislak, C. L., Beaulieu, A. M., Loeb, G. B., Karo, J., Canner, D., Bezman, N. A., et al. (2013). Stage-specific regulation of natural killer cell homeostasis and response against viral infection by microRNA-155. Proc. Natl. Acad. Sci. U.S.A. 110, 6967-6972. doi: 10.1073/pnas.1304410110

Zhang, G., Li, N., Li, Z., Zhu, Q., Li, F., Yang, C., et al. (2015). microRNA4717 differentially interacts with its polymorphic target in the PD1 3 untranslated region: a mechanism for regulating PD-1 expression and function in HBV-associated liver diseases. Oncotarget 6, 18933-18944 doi: 10.18632/oncotarget.3662

Zhou, Q., Haupt, S., Prots, I., Thümmler, K., Kremmer, E., Lipsky, P. E., et al. (2013). miR-142-3p is involved in CD25 + CD4 T cell proliferation by targeting the expression of glycoprotein A repetitions predominant. J. Immunol. 190, 6579-6588. doi: 10.4049/jimmunol.1202993

Conflict of Interest: The authors declare that the research was conducted in the absence of any commercial or financial relationships that could be construed as a potential conflict of interest.

Copyright (c) 2020 Pesce, Greppi, Ferretti, Obino, Carlomagno, Rutigliani, Thoren, Sivori, Castagnola, Candiani and Marcenaro. This is an open-access article distributed under the terms of the Creative Commons Attribution License (CC BY). The use, distribution or reproduction in other forums is permitted, provided the original author(s) and the copyright owner(s) are credited and that the original publication in this journal is cited, in accordance with accepted academic practice. No use, distribution or reproduction is permitted which does not comply with these terms. 